\title{
Comparative techniques to quantify cyanobacteria dominated epilithic biofilms on tropical rocky shores
}

\author{
Sanjay Nagarkar ${ }^{1, *}$, Gray A. Williams ${ }^{1,2}$ \\ 'Department of Ecology and Biodiversity, ${ }^{2}$ The Swire Institute of Marine Science, The University of Hong Kong, \\ Pokfulam Road, Hong Kong
}

\begin{abstract}
The epilithic biofilm of tropical shores is dominated by cyanobacteria with only a sparse cover of diatoms. Geographical comparison of biofilms is difficult, however, due to variation in enumeration techniques. This paper describes techniques to quantify the biof $1 \mathrm{~m}$ in an attempt to standardize comparative studies. Species nchness and relative abundance were best enumerated using scanning electron microscope (SEM) images of alr dried rock chips, as compared to light, epifluorescence and confocal laser microscopy. SEM preparations provided clear images and allowed identification of most species. Air dried and Cryo-stage preparatıons provided the least damaged images of species whereas the harsh dehydration process in critıcal-pount dried specimens damaged morphology and removed loosely attached species resulting in underestimation of species richness and abundance. $A$ combunation of SEM techniques (e.g. Cryo-stage, air dried and critical-pont dried samples) is recommended for initıal species identıfication. Chlorophyll a extraction from rock chips, as an indirect estimate of biomass, was more efficient using methanol or ethanol as compared to acetone. Methanol heated for $2 \mathrm{~min}$ and cooled for 12 h ylelded $100 \%$ chlorophyll a extraction while cold methanol, methanol heated for 2 min and cooled for 3 and $6 \mathrm{~h}$, and ethanol heated for $5 \mathrm{~min}$, extracted greater than $95 \%$ chlorophyll a. No significant loss of chlorophyll a was recorded in rock samples stored in moist or dry conditions at $4^{\circ} \mathrm{C}$ or room temperature for 24 h or at $-20^{\circ} \mathrm{C}$ for a month, but in samples stored at $4^{\circ} \mathrm{C}$ or room temperature for a week, 60 to $75 \%$ loss occurred. Chlorophyll a, once extracted, can be stored for a week in the dark prior to measurement without significant loss. To standardize techniques for tropical, cyanobacteria-rich epilithic biofilms, chlorophyll a extraction of rock chips using cold methanol is recommended.

KEY WORDS: Biofilm Cyanobacteria Epilithic Hong Kong - Tropical rocky shore
\end{abstract}

\section{INTRODUCTION}

Intertidal, epilithic biofilms are 3 -dimensional structures composed of a variety of species. Temperate shore biofilms are dominated by diatoms with patches of cyanobacteria and photo-autotrophic bacteria embedded in a mucopolysaccharide matrix which provides an attachment site for spores of macroalgae and invertebrates (Hill \& Hawkins 1991). On tropical shores, in contrast, cyanobacteria dominate the biofilm, being better able to tolerate high temperatures

-E-mail: nagarkar@travelin.com than diatoms (Potts 1980). The biofilm plays a major role in primary production on rocky shores and is the energy base of the benthic food web. Despite this role, the biofilm has received scant attention due to the difficulties associated with its sampling and quantification (Underwood 1984a, b, MacLulich 1987, Hill \& Hawkins 1990, 1991. Thompson et al. 1996)

Previously the biofilm has been studied using light and epifluorescence microscopy of samples scraped from rock surfaces (Castenholz 1963, Nicotri 1977 , Underwood 1984a, b, MacLulich 1987). Comparative studies of techniques to investigate temperate, epilithic biofilms have been reported by MacLulich (1986a) and Hill \& Hawkins (1990). MacLulich (1986a) 
studied various sampling procedures, comparing different microscopy techniques (e.g light, epifluorescence and scanning electron microscopy, SEM) and also chlorophyll a analysis. Working on sandstone shores in Australia, MacLulich removed the biofilm by brushing with a toothbrush to form a slurry, and estimated species diversity and abundance by light microscopy (MacLulich 1986a). This method is not, however, universally suitable as the effectiveness of biofilm removal with a toothbrush varies with rock hardness and capacity of the biofilm to adhere to the rock surface (Hill \& Hawkins 1990, Nagarkar pers. obs.). Scraping stone surfaces can result in an underestimation of freshwater algal populations (Jones 1974) and destroys the 3-dimensional integrity and architecture of the sample. Hill \& Hawkins (1990) used SEM photographs of intact rock chips as a standard method and found air drying to be the most appropriate preparation technique.

Techniques for the measurement of chlorophyll a to estimate algal biomass are well established, although most studies have concentrated on planktonic populations (e.g. Marker 1972, Sand-Jensen 1976, HolmHansen \& Riemann 1978, Jespersen \& Christoffersen 1987). Although acetone is commonly used as a solvent (Underwood 1984a, b, MacLulich 1986a), hot methanol appears a more efficient solvent for epilithic biofilms (Hill \& Hawkins 1990). Methanol vapour is, however, toxic if inhaled and is therefore not widely used. Some studies (Moed \& Hallegraeff 1978, Nusch 1980, Arvola 1981) have shown that the extraction efficiency of ethanol is similar to methanol resulting in ethanol being adopted as a safe alternative solvent (Nusch \& Palme 1975, Jespersen \& Christoffersen 1987) and as a standard by some countries (e.g. Denmark: Danish. standard DS 1985; Switzerland: ISO 10260 1992).

Chlorophyll a extraction has been performed under a variety of heating (Jespersen \& Christoffersen 1987) and cooling protocols (ISO 10260 1992, Meyns et al. 1994) in order to achieve efficient extraction. In the case of epilithic biofilms, workers have also used various sampling methods, such as brushing or scraping the biofilm (Underwood 1984a, b), grinding rock chips (Dye \& White 1991) or removing intact rock chips (Hill \& Hawkins 1990, 1991. Williams 1993, 1994a, b). Chlorophyll a has been extracted using acetone (Nicotri 1977, MacLulich 1986a), 2:1 chloroform/ methanol mixture (Wood 1985, Dye \& White 1991), ethanol (Takada 1993) and hot methanol (Hill \& Hawkins 1991; although these workers appear to use the same equation for methanol and acetone and the appropriate equation from HMSO 1986 is misquoted) using single (e.g Hill \& Hawkins 1991, Williams 1993) or double (Underwood 1984a, b) extraction. Chlorophyll a extraction is often species specific and incom- plete after a single extraction (Jespersen \& Christoffersen 1987). Samples from the shore sometimes cannot be immediately analyzed and have had to be stored (Dye \& White 1991). Different storage protocols will also influence the comparative value of the final chlorophyll a concentration

Although chlorophyll a values have been reported from intertidal areas around the world (e.g North America: Nicotri 1977; Australia. Underwood 1984a, b, MacLulich 1986a; UK: Hill \& Hawkins 1991; South Africa: Dye \& White 1991, Bustamante et al. 1995; Hong Kong: Williams 1993, 1994a, b), their comparative value is limited due to the varying sampling and extraction protocols used. Variation in microscopy techniques, resulting in specific biases in identification of biofilm species under various preservation and preparation techniques, also confound geographical comparisons. The aim of this study was to develop simple, reliable techniques to enumerate the species richness and abundance of cyanobacteria dominated, epilithic biofilms and which will allow the handling of the relatively large number of samples required for ecological experiments whilst maintaining an acceptable level of accuracy.

\section{MATERIALS AND METHODS}

Site and sample collection. Samples were collected at low tide from a $20 \mathrm{~m}$ long horizontal belt in the mid eulittoral (1.5 $\mathrm{m}$ above Chart Datum) on a semiexposed rocky shore at Cape d'Aguilar, Hong Kong (Nagarkar 1996). For light microscopy, 25 glass slides were fixed with silicon-glue (Carter's cement, Avery Dennison) to the rock in October 1994 and collected after $4 \mathrm{wk}$ growth of the biofilm (considered adequate for the development of an 'end-point' algal community, MacLulich 1986b). For epifluorescence, confocal laser and SEM, 150 rock chips $\left(\sim 1 \mathrm{~cm}^{2}\right)$ were collected using hammer and chisel, and divided into 6 sets of 25 chips. To investigate the efficiency of different extraction protocols, 150 rock chips $\left(\sim 5 \mathrm{~cm}^{2}\right)$ were collected from a homogeneous area $\left(\sim 2 \mathrm{~m}^{2}\right)$ in March 1994 and divided into 25 sets of 6 from which chlorophyll a was extracted.

Microscopy techniques. Percentage cover of the biofilm was scored under light, epifluorescence, confocal laser and scanning electron (SEM) microscopes. Advantages and disadvantages of each technique were qualitatively evaluated. Glass slides were observed under light microscope (Leitz Wetzlar). Ten random fields at fixed magnification $(400 \times)$ were photographed from each slide. Two sets of rock chips were analysed within $2 \mathrm{~h}$ of collection, one set under the epifluorescence (Leica fluovert FU), and the other set 
under the confocal laser microscope (Nikon, Bio-Rad MRC 600). Ten random fields were photographed from each rock chip at a fixed magnification $(200 \times)$. A third set of rock chips was fixed in $2.5 \%$ glutaraldehyde for 1 to $2 \mathrm{~h}$, air dried overnight and stored in a vacuum desiccator. Rock chips were coated with a gold/palladium mixture for $30 \mathrm{~min}$ and observed under the SEM (Leica Cambridge S440) at fixed magnification (500×). Ten random fields were photographed from each rock chip. An overlay of 100 evenly-spaced points was used to score percentage cover of the biofilm from all the photographs $(9 \times 6 \mathrm{~cm})$.

On the basis of these investigations, the SEM was chosen as a standard method and different preservation and sample preparation methods were compared. Two sets $(n=25)$ of rock chips were fixed with $2.5 \%$ glutaraldehyde for 1 to $2 \mathrm{~h}$; one set was air dried overnight, and the second was dehydrated in an alcohol series and critical-point dried; both sets were observed under the SEM. A third set of 25 rock chips was freezedried and observed under low temperature, Cryostage SEM. In all cases 10 random fields were photographed at fixed magnification $(500 \times)$ from each rock chip and percentage cover of the biofilm scored from a 100-point overlay. Cyanobacteria were identified using the key of Desikachary (1959).

Chlorophyll a extraction techniques. Effect of solvents and various protocols on chlorophyll a extraction: The basic experimental protocol followed that recommended by HMSO (1986). Chlorophyll a was extracted with 3 cold solvents; $90 \%$ acetone, absolute methanol and $96 \%$ ethanol at $4^{\circ} \mathrm{C}$ for $24 \mathrm{~h}$. Extraction efficiency was also investigated for methanol and ethanol using different heating and cooling protocols; cold methanol and ethanol $\left(4^{\circ} \mathrm{C}\right)$ for $24 \mathrm{~h}$, hot (boiling) methanol and ethanol for $30 \mathrm{~s}, 2$ and $5 \mathrm{~min}$ with $1 \mathrm{~min}$ cooling time and cooling times of 3,6 and $12 \mathrm{~h}$ for methanol and ethanol heated for 2 min. All extractions were performed twice in fresh solvent to verify relative extraction efficiency. To ensure that all chlorophyll a was extracted, a third extraction was performed and in all cases no extra chlorophyll a was recorded. After cooling, the extract was filtered and absorbance was measured at 665 and $750 \mathrm{~nm}$ (Pye Unicam PU 8600 UV/VIS spectrophotometer), the extract was acidified with $10 \% \mathrm{HCl}$ and absorbance was again measured at 665 and $750 \mathrm{~nm}$ to correct for phaeophytins. The surface area of the rock chips was reproduced by covering the exposed surface with aluminium foil and measured using an Area meter (LI-3100 Area meter). Chlorophyll a $\left(\mu \mathrm{g} \mathrm{cm}^{-2}\right)$ was calculated using equations for acetone and methanol (HMSO 1986) and ethanol (Wintermanns \& DeMots 1965).

Effect of sample storage conditions on chlorophyll a extraction: Four sets of 6 rock chips were stored under different conditions. Sets were kept at room temperature or at $4^{\circ} \mathrm{C}$, and stored either moist with seawater ( 2 to 3 drops) or in a dry condition. Chlorophyll a was extracted by double extraction $24 \mathrm{~h}$ after collection, using hot methanol heated for $30 \mathrm{~s}$ and cooled for 1 min.

A further 4 sets of rock chips were used to investigate the effect of different storage methods over a longer time period. One set was stored in a refrigerator at $4^{\circ} \mathrm{C}$ for $1 \mathrm{wk}$, a second at room temperature for $1 \mathrm{wk}$ and a third set frozen for 1 mo at $-20^{\circ} \mathrm{C}$. All the samples were kept in the dark. The chlorophyll a content of the stored samples was compared with extracts from fresh samples taken at the initial sample time which were treated as controls. To assay loss of chlorophyll a with time, chlorophyll a extracts in hot methanol (heated for $30 \mathrm{~s}$ and cooled for $1 \mathrm{~min}$, double extraction) were stored at $4^{\circ} \mathrm{C}$ in the dark and measured at $0 \mathrm{~h}$, and after 1,3 and $7 \mathrm{~d}$.

Statistical methods. The efficiency of different protocols was assessed by determining the percentage efficiency of the first extraction as compared to the final overall extraction which was treated as a complete extraction $100 \%$ extractable chlorophyll a removed from the rock). Percentage data were arc-sin transformed and analysed by 2 -way analysis of variance (ANOVA). Student-Neuman-Keuls (SNK) tests were performed to investigate significant differences between means (Zar 1984). Data for the extraction efficiency of various solvents and storage experiments were tested for normality (Anderson-Darling Normality test) and homogeneity of variances (Cochran's variance test) and chlorophyll a values were directly compared between treatments and control samples using 1-way ANOVA.

\section{RESULTS}

\section{Microscopy techniques}

The biofilm supported a mixed assemblage of microand macroalgae but was principally composed of cyanobacteria (Figs. 1 \& 2). Only species with welldefined, characteristic morphologies (e.g. Kyrtuthrix maculans, Lyngbya martensiana) could be initially identified using light, epifluorescence and confocal laser microscopy. Other species could only be scored under broad morphological groups (e.g. filamentous or unicellular cyanobacteria), irrespective of their genera. Biofilm cover was high (almost 100\%, Table 1) in all treatments but the distribution of individual species/ morphological groups was very patchy (large SD values; Table 1). Filamentous cyanobacteria (e.g. Lyngbya spp.) dominated the glass slides with the encrusting 

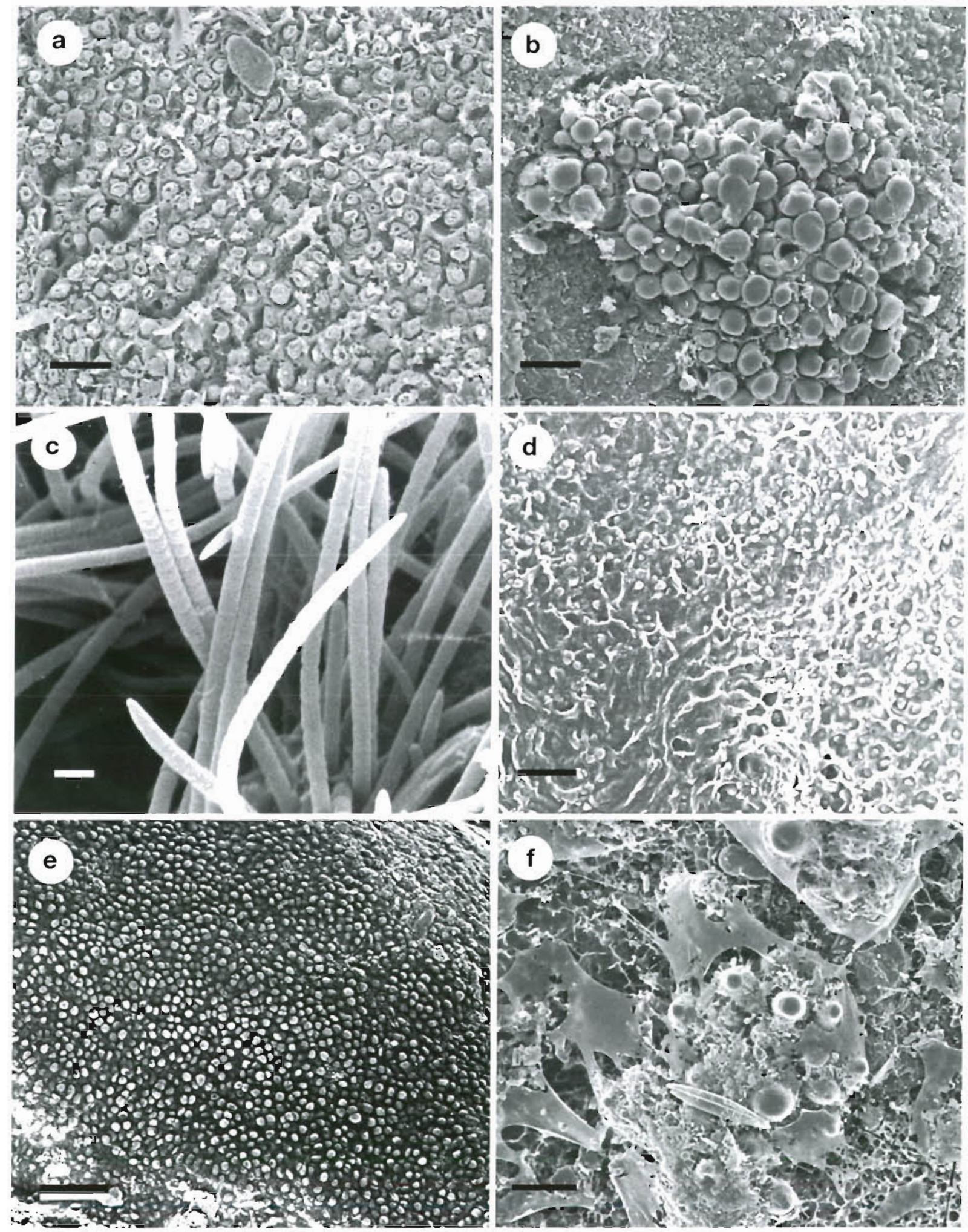

Fig. 1. Selected Cryo-stage and critical-point dried SEM photographs of the tropical intertidal, epilithic biofilm. (a) Damaged surface morphology of Hapalospongidıon gelatinosum under critical-point dried SEM where spherical upper layer cells appear mis-shapen. (b) Shrunken Dermocarpa sp. under critical-point dried SEMi cells are puriform in normal condition. (c) Clear image of Oscillatona of. earlei under critical-point dried SEM. (d) Clear image of surface morphology of encrusting cyanobacterium Kyrtuthrix maculans under Cryo-stage SEM. (e) Clear image of unicellular cyanobacterium Gloeocapsa under Cryo-stage SEM (f) lce layer on the biofilm under Cryo-stage SEM, which obscures a clear image. Scale bars: $(a, b, d, e, f)=20 \mu \mathrm{m}$; $(c)=2 \mu \mathrm{m}$ 

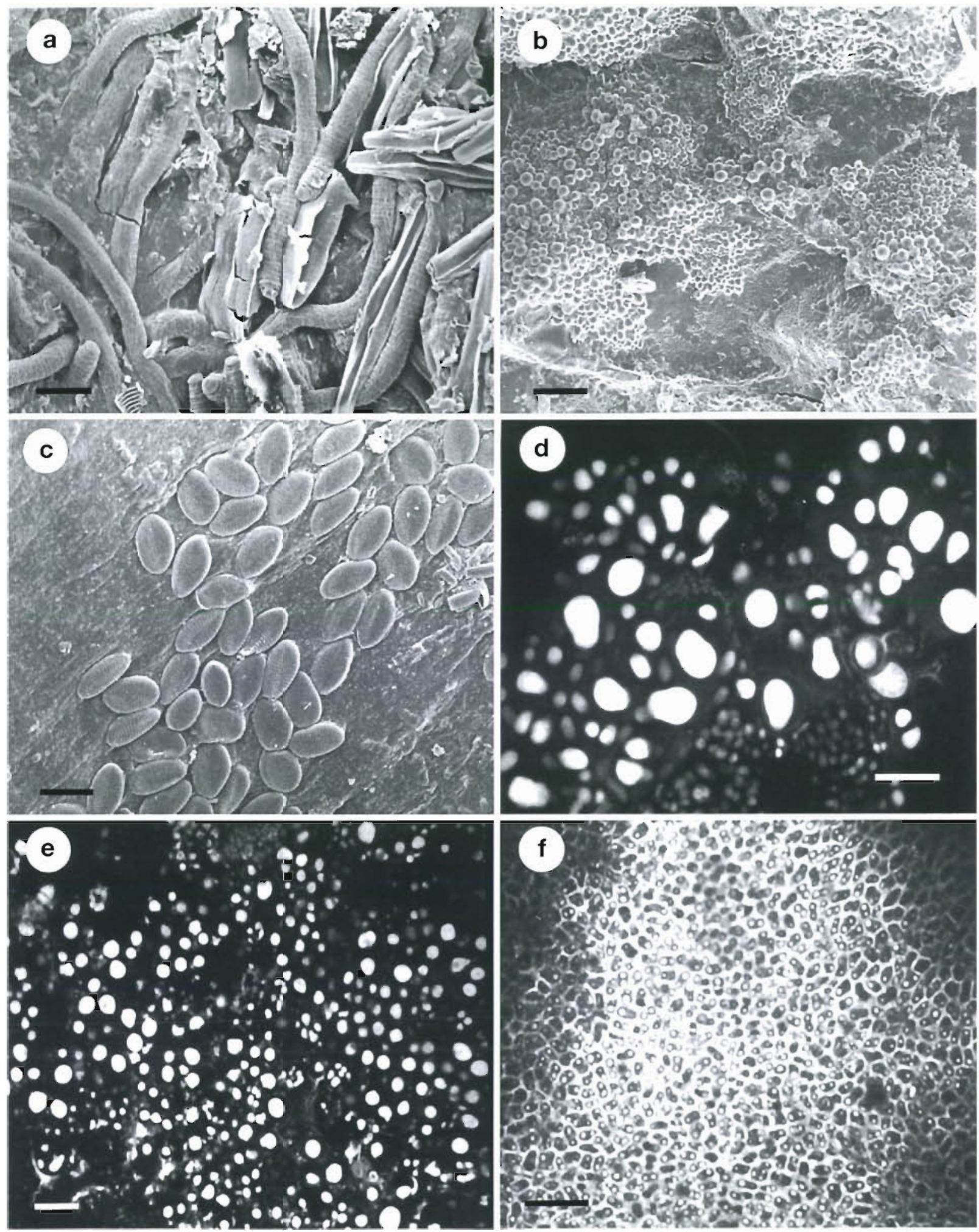

Fig. 2. Selected confocal laser and air dried SEM photogiaphs of the tropical intertidal, epulthic biofllm (a) Shrunken Oscillatoria vizagapatensis under air dried SEM where the cross wall of filaments is not clearly visible; species identification can be made by the presence of calyptra and filament width (b) Clear image of unicellular cyanobacterium Chroococcus sp under air dried SEM. (c) Clear image of diatoms (Cocconels sp.) under arr dried SEM. (d) Confocal laser image of Dermocarpa sp (e) Confocal image of unicellular cyanobacterium Gloeocapsa sp (f) Surface morphology of Kyrtuthrix maculans under confocal laser microscope showing apical cells of filaments which are compactly arranged and surrounded by a mucilaginous sheath $\mathrm{Scale}$ bars $=20 \mu \mathrm{m}$ 
Table 1 Mean percentage cover $( \pm S D, n=25)$ of the biofılm assemblage scored under light, epifluorescence and confocal laser microscopes

\begin{tabular}{|lrrr|}
\hline \multirow{2}{*}{$\begin{array}{l}\text { Algael } \\
\text { cyanobacteria }\end{array}$} & Glass slides & \multicolumn{2}{c|}{ Rock chips } \\
Light & \multicolumn{1}{c}{ Epifluorescence } & Confocal laser \\
Filamentous cyanobacteria & $57.40 \pm 40.74$ & $6.90 \pm 25.79$ & $6.48 \pm 17.64$ \\
Unicellular cyanobacteria & $8.35 \pm 13.44$ & $52.00 \pm 50.59$ & $53.48 \pm 49.53$ \\
Kyrtuthrix maculans & $20.00 \pm 41.04$ & $37.66 \pm 49.04$ & $40.03 \pm 46.12$ \\
Calothrix spp. & $9.25 \pm 21.90$ & Not present & Not present \\
Hildenbrandia rubra & Not present & $3.45 \pm 18.57$ & Not present \\
& & & \\
\hline
\end{tabular}

Table 2. Mean percentage cover ( $\pm \mathrm{SD}, \mathrm{n}=25$ ) of the biofilm assemblage preserved by Cryo-stage, critical-point and air drying scored under the scanning electron microscope (SEM)

\begin{tabular}{|lrrr|}
\hline Algae/cyanobacteria & Cryo-stage & Crıtical-point dried & Air dried \\
\hline Lyngbya, Oscillatoria & $15.02 \pm 33.88$ & $42.29 \pm 45.09$ & $29.55 \pm 42.17$ \\
Unicellular cyanobacteria & $20.27 \pm 39.39$ & $3.38 \pm 17.26$ & $13.06 \pm 27.90$ \\
Kyrtuthrix maculans & $33.62 \pm 46.26$ & $15.82 \pm 35.68$ & $7.20 \pm 24.37$ \\
Calothrix spp. & Not present & Not present & $2.58 \pm 6.24$ \\
Hildenbrandia rubra & $6.37 \pm 21.52$ & $2.94 \pm 17.15$ & $4.47 \pm 14.32$ \\
Diatoms & $11.57 \pm 29.91$ & $3.62 \pm 11.22$ & $21.02 \pm 31.88$ \\
Hapalospongidion gelatinosum & $13.12 \pm 32.52$ & $31.26 \pm 46.07$ & $9.69 \pm 28.27$ \\
\hline
\end{tabular}

Table 3. Qualitative observation (500x) for preservation status of algae and cyanobacteria during various SEM preparations. Good: high quality image after preparation; normal: surface morphology visible only at higher magnifications $(>800 \times$ ) shrunken: shrinkage of sample's $3-D$ structure during preparation; damage (e.g cracks): surface morphology of samples damaged. Norm.-shr. normal-shrunken

\begin{tabular}{|llll|}
\hline Algae/cyanobactera & Cryo-stage & Critical-point dried & Air dried \\
\hline Filamentous cyanobacteria & Shrunken & Good & Norm.-shr \\
Unicellular cyanobacteria & Good & Norm.-shr. & Normal \\
Kyrtuthrix maculans & Good & Normal & Normal \\
Diatoms & Good & Normal & Good \\
Hapalospongidion gelatinosum & Normal & Damage & Good \\
\hline
\end{tabular}

was the most abundant species followed by unicellular cyanobacteria in freeze-dried samples although Lyngbya spp., diatoms and Hapalospongidion were also present.

Various SEM preparation techniques gave clear images of different species of cyanobacteria allowing their identification (Table 3, Figs. 1 \& 2). Critical-point drying was suitable for filamentous cyanobacteria, although unicellular cyanobacteria sometimes appeared shrunken and the surface morphology of Hapalospongidion was damaged (Fig. 1). Cryo-stage revealed sharp images of diatoms, unicellular cyanobacteria and the encrusting cyanobacterium Kyrtuthrix, but filamentous cyanobacteria appeared shrunken. In air dried samples, however, many species appeared shrunken after preservation (Table 3, Fig. 2). Air dried samples revealed the maximum number of cyanobacteria and diatom species which included 3 species of unicellular cyanobacteria, 4 species of Lyngbya and Oscillatoria, 3 species of Calothrix and 6 species of diatoms (Table 4). Other SEM techniques revealed fewer unicellular cyanobacteria species, Lyngbya, Oscillatoria and diatoms and no Calothrix species (Table 4). Kyrtuthrix and other encrusting species were found in similar numbers in all 3 techniques. cyanobacterium $K$. maculans being the second most abundant group. Calothrix species and unicellular cyanobacteria were also present. Rock chips viewed under epifluorescence and confocal laser microscopes were dominated by Kyrtuthrix and unicellular cyanobacteria (Table 1), filamentous cyanobacteria and the red encrusting alga Hildenbrandia rubra were sparse.

Species cover using various SEM preparation techniques was also consistently high (almost 100\%; Table 2), although distribution was again very patchy. Lyngbya spp. dominated the critical-point dried samples with Kyrtuthrix and the encrusting Phaeophyte Hapalospongidion gelatinosum being the second and third most abundant species (Table 2). Air dried rock chips were dominated by Lyngbya spp. and diatoms; unicellular cyanobacteria, Kyrtuthrix and Hapalospongidion were also present. In contrast, Kyrtuthrix

\section{Chlorophyll a extraction techniques}

\section{Effect of solvents and various protocols on chlorophyll a extraction}

Cold methanol and ethanol were equally efficient at extracting chlorophyll a but were more efficient than acetone (Fig 3; SNK test after 1-way ANOVA; df = $2,20, F=12.56 ; p<0.001)$. Chlorophyll a extraction efficiency in methanol and ethanol increased with length of heating from $60 \%$ after 30 s to over $95 \%$ with variable cooling times after 2 min heating, or when used cold. No significant difference in chlorophyll a extraction efficiency was found between methanol and ethanol (Tables $5 \& 6$ ). Chlorophyll a extraction efficiency of solvents heated for 2 min and cooled for $12 \mathrm{~h}$ was not significantly different from cold solvents, sol- 
Table 4. Variety of species found using various preparation techniques observed under SEM

\begin{tabular}{|c|c|c|c|}
\hline \multirow{2}{*}{$\begin{array}{l}\text { Alga/cyano- } \\
\text { bacteria/form }\end{array}$} & \multicolumn{3}{|c|}{ - Species found } \\
\hline & Cryo-stage & Critical-point dried & Air dried \\
\hline $\begin{array}{l}\text { Unicellular } \\
\text { cyanobacterıa }\end{array}$ & $\begin{array}{l}\text { Dermocarpa sp. } \\
\text { Gloeocapsasp. }\end{array}$ & Gloeocapsasp. & $\begin{array}{l}\text { Chroococcus minor } \\
\text { Dermocarpa sp. } \\
\text { Gloeocapsa sp. }\end{array}$ \\
\hline $\begin{array}{l}\text { Lyngbya } \\
\text { Oscllatona }\end{array}$ & $\begin{array}{l}\text { Lyngbya martensiana } \\
\text { Lyngbya semuplena } \\
\text { Oscillatona cf. earlei }\end{array}$ & $\begin{array}{l}\text { L. martensiana } \\
\text { L. semiplena } \\
\text { O. cf. earlei }\end{array}$ & $\begin{array}{l}\text { L. martensiana } \\
\text { L. semiplena } \\
\text { O. cf earleı } \\
\text { O. vizagapatensis }\end{array}$ \\
\hline Calothrix & & & $\begin{array}{l}\text { C. scopulorum } \\
\text { C. crustacea } \\
\text { C. contarenii }\end{array}$ \\
\hline Kyrtuthrix & Kyrtuthrix maculans & K. maculans & K. maculans \\
\hline Diatoms & $\begin{array}{l}\text { Achnanthes sp. } \\
\text { Navicula sp. } 1 \\
\text { Navicula sp. } 2 \\
\text { Navicula sp. } 3 \\
\text { Cocconeis sp. }\end{array}$ & $\begin{array}{l}\text { Achnanthes sp. } \\
\text { Navicula sp. } 1 \\
\text { Navicula sp. } 2 \\
\text { Navicula sp. } 3\end{array}$ & $\begin{array}{l}\text { Achnanthes sp. } \\
\text { Navicula sp. } 1 \\
\text { Navicula sp. } 2 \\
\text { Navicula sp. } 3 \\
\text { Skeletonema sp. } \\
\text { Grammatophora sp. }\end{array}$ \\
\hline $\begin{array}{l}\text { Encrusting } \\
\text { algae }\end{array}$ & $\begin{array}{l}\text { Hildenbrandia rubra } \\
\text { Hapalospongidion gelatinosum }\end{array}$ & $\begin{array}{l}\text { H. rubra } \\
\text { H. gelatinosum }\end{array}$ & $\begin{array}{l}\text { H. rubra } \\
\text { H. gelatinosum }\end{array}$ \\
\hline
\end{tabular}

vents cooled for $3 \mathrm{~h}$ and solvents heated for $5 \mathrm{~min}$ but was more etficient than other treatments. No significant differences were found, however, between cold solvents, solvents cooled for 3 and $6 \mathrm{~h}$ and solvents heated for $5 \mathrm{~min}$ although these treatments were more efficient than other treatments (Tables $5 \& 6$ )

Chlorophyll a extraction efficiency of both solvents with all the protocols, was significantly greater than ethanol heated for $2 \mathrm{~min}$ and methanol heated for 30 s. Methanol

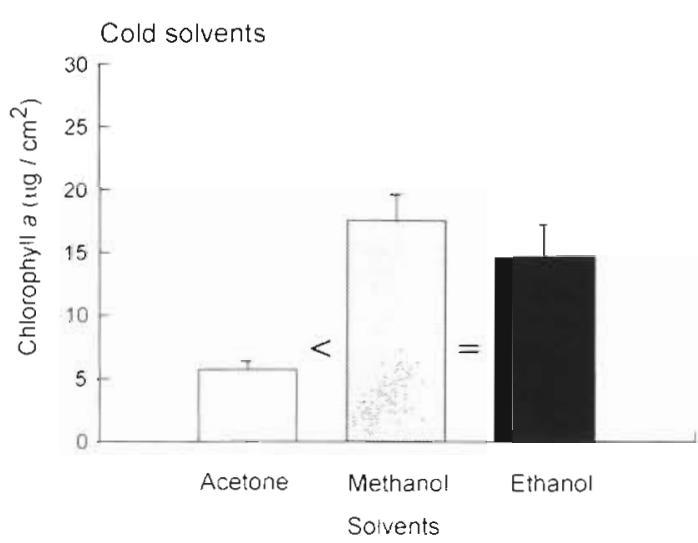

Fig. 3. Mean chlorophyll a concentration extracted $(+\mathrm{SE}, \mathrm{n}=6$ ) by cold $90 \%$ acetone, absolute methanol and $96 \%$ ethanol. Results of SNK tests are indicated heated for 2 min and cooled for $12 \mathrm{~h}$ was, however, significantly more efficient than all other treatments which used 2 min or less heating time and ethanol heated for 2 min and cooled for $6 \mathrm{~h}$, but was as efficient as the remaining treatments (Tables $5 \& 6$ ).

Table 5. Extraction efficiency (\% extraction) of methanol and ethanol in single and double extraction under different heating and cooling protocols as compared to maximum extraction verified by a third extraction. All the Heated solvents were cooled for 1 min and all the

Cooled solvents were heated for 2 min (see 'Materials \& methods')

\begin{tabular}{|c|c|c|c|}
\hline Solvent & Protocol & $\begin{array}{c}\text { Single extraction } \\
(\% \pm \text { SD })\end{array}$ & $\begin{array}{c}\text { Double extraction } \\
(\% \pm \mathrm{SD})\end{array}$ \\
\hline Methanol & Cold (for $12 \mathrm{~h}$ ) & $95.83 \pm 4.70$ & $4.10 \pm 0.52$ \\
\hline Methanol & Heated 5 min & $92.77 \pm 3.64$ & $7.72 \pm 1.23$ \\
\hline Methanol & Heated 2 min & $82.38 \pm 2.66$ & $17.61 \pm 1.16$ \\
\hline Methanol & Heated $30 \mathrm{~s}$ & $59.44 \pm 9.29$ & $40.55 \pm 2.39$ \\
\hline Methanol & Cooled for $3 \mathrm{~h}$ & $94.93 \pm 8.51$ & $5.06 \pm 0.94$ \\
\hline Methanol & Cooled for $6 \mathrm{~h}$ & $94.39 \pm 7.17$ & $5.60 \pm 0.47$ \\
\hline Methanol & Cooled for $12 \mathrm{~h}$ & $99.16 \pm 12.02$ & $0.83 \pm 0.23$ \\
\hline Ethanol & Cold (for $12 \mathrm{~h}$ ) & $88.66 \pm 4.54$ & $11.33 \pm 2.23$ \\
\hline Ethanol & Heated 5 min & $95.85 \pm 9.35$ & $3.38 \pm 0.64$ \\
\hline Ethanol & Heated 2 mun & $70.83 \pm 2.05$ & $29.16 \pm 0.77$ \\
\hline Ethanol & Heated $30 \mathrm{~s}$ & $81.81 \pm 1.99$ & $18.18 \pm 0.64$ \\
\hline Ethanol & Cooled for $3 \mathrm{~h}$ & $91.69 \pm 7.60$ & $8.30 \pm 0.56$ \\
\hline Ethanol & Cooled for $6 \mathrm{~h}$ & $83.73 \pm 5.11$ & $16.26 \pm 1.39$ \\
\hline Ethanol & Cooled for $12 \mathrm{~h}$ & $92.58 \pm 6.19$ & $7.41 \pm 0.89$ \\
\hline
\end{tabular}


Table 6. Two-way ANOVA to unvestigate chlorophyll a extraction efficiency (\% extractıon) in single extractions under varıous protocols; significant differences further analysed by SNK multiple comparison tests (Zar 1984). Data were arc-sin transformed.

Treatments underlined are not significantly different. $\cdots p<0.001$; NS: not significant; $n=6$

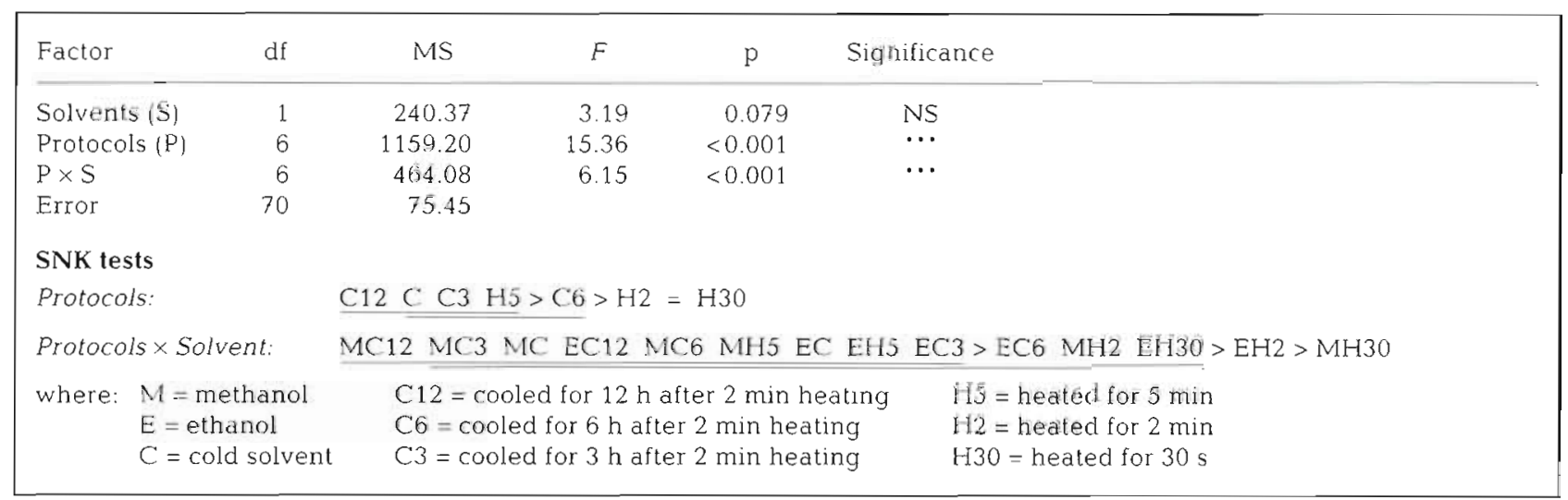

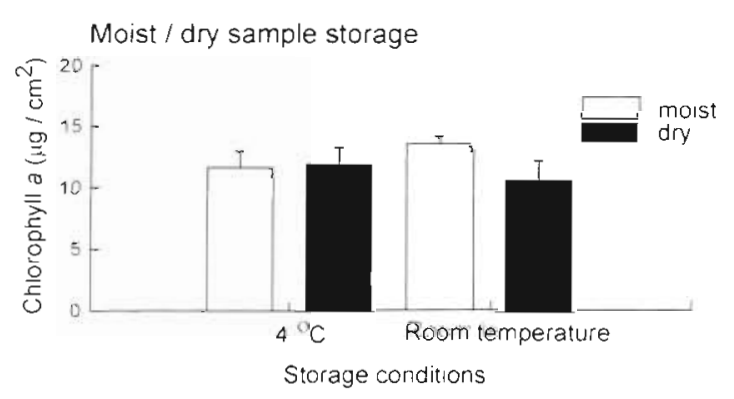

Fig. 4. Mean chlorophyll a concentration extracted $(+\mathrm{SE}, \mathrm{n}=$ 6) in hot methanol (Hill \& Hawkins 1990) when samples were stored in morst and dry conditions at $4^{\circ} \mathrm{C}$ and room temperature

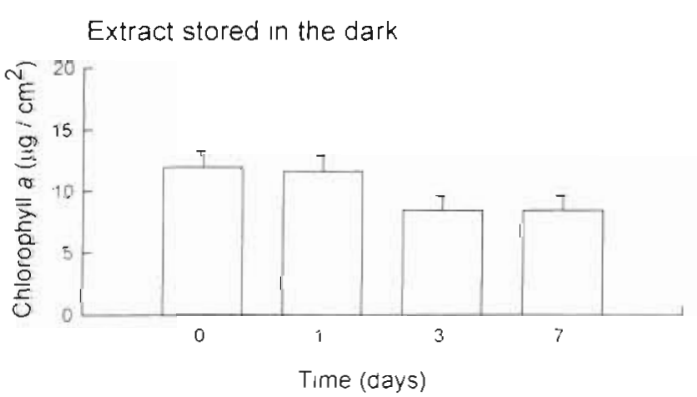

Fig. 5. Mean chlorophyll a concentration extracted (+SE, $\mathrm{n}=6$ ) from fresh samples (time 0) in hot methanol (Hill \& Hawkins 1990) stored in the dark over a period of 1 wk

Effect of sample storage conditions on chlorophyll a extraction

Chlorophyll a extraction efficiency did not vary between samples stored moist or dry at $4^{\circ} \mathrm{C}$ and room temperature (Fig. 4; 1-way ANOVA; df 3,20; $F=0.73$; $\mathrm{p}=0.544)$. There was also no significant decrease in

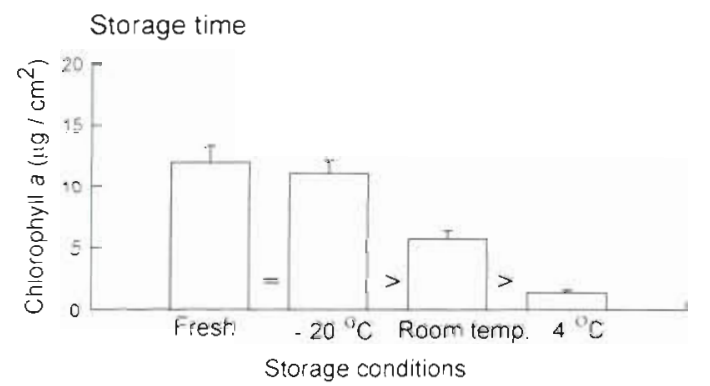

Fig. 6. Mean chlorophyll a concentration extracted $(+\mathrm{SE}, \mathrm{n}=$ 6) in hot mothanol (Hill \& Hawkins 1990) from fresh samples and samples pre-stored for 1 wk at $4^{\circ} \mathrm{C}$, at room temperature and at $20^{\circ} \mathrm{C}$ for $4 \mathrm{wk}$. Results of SNK tests are indicated

chlorophyll $a$ when stored in the dark for up to a week (Fig. 5; 1 -way ANOVA; df 3, 20; $F=2.15 ; \mathrm{p}=0.126$ ). There was, however, a significant loss of chlorophyll a when samples were stored at room temperature and $4^{\circ} \mathrm{C}$ for 1 wk as compared to fresh samples, although no significant loss of chlorophyll a was recorded when samples were stored at $-20^{\circ} \mathrm{C}$ for $4 \mathrm{wk}$ (Fig. 6 ; SNK test after 1 -way ANOVA; df 3,$20 ; F=26.36 ; \mathrm{p}<0.001$ ).

\section{DISCUSSION}

The intertidal, epilithic biofilm in Hong Kong is composed of various species of cyanobacteria, especially the encrusting Kyrtuthrix maculans in the upper eulittoral; other species include Calothrix, Lyngbya, Oscillatoria, Phormidium spp., and many unicellular species of which Chroococcus, Dermocarpa and Gloeocapsa spp. are dominant. The biofilm also supported diatoms, encrusting red and brown algae and sporelings of macroalgae seasonally (Nagarkar 1996). In contrast, 
temperate rocky shore biofilms are dominated by diatoms, with spores and sporelings of macroalgae and a sparse cover of cyanobacteria (see Hill \& Hawkins 1991), although Thompson et al. (1996) suggest cyanobacteria may have underestimated by the techniques employed by Hill \& Hawkins (1991). In southern temperate Australia, however, the biofilm mainly consists of the cyanobacterium Anacystis sp. with sparse cover of Chroococcus, Lyngbya and Oscillatoria spp., although diatoms, spores and sporelings of macroalgae were also present (MacLulich 1987)

\section{Microscopy techniques}

There have been few comparative microscopy studies reported on intertidal, epilithic biofilms (see MacLulich 1986a, Hill \& Hawkins 1990). MacLulich (1986a) concluded that light microscope studies of biofilms grown on glass slides for $4 \mathrm{wk}$ or collected by toothbrushing the rock were suitable techniques for routine sampling in south Australia. Assessing the biofilm accumulated on glass slides using the light microscope was difficult in the present study as the thick film prevented the passage of adequate light for image resolution. Although light microscopy has been used successfully to score biofilm abundance (Nicotri 1977 Underwood 1984a, MacLulich 1987), this technique is not recommended as only long, filamentous cyanobacteria (e.g. Lyngbya martensiana) and unicellular cyanobacteria (e.g. Chroococcus and Dermocarpa spp.) could be observed clearly and identified under the light microscope

Difficulties in species identification, even to generic level, were also encountered with the epifluorescence microscope. Only species with distinct morphologies could be identified and species with similar morphology had to be grouped together (i.e. filamentous or unicellular cyanobacteria) in order to score percentage cover. Jones (1974), however, successfully used this technique to analyse in situ freshwater epilithic diatom. populations. Raghukumar et al. (1992) were able to classify epiphytic fungi (thraustochytrids) on marine algae as these species have distinct morphological forms. In the present study, the uneven topography of the rock surface made focusing difficult, limiting the full utilization of the epifluorescence microscope and risked damage to the objective lens at magnifications above $200 \times$ which are needed to resolve morphological details important for species identification.

Similar problems were associated with the confocal laser microscope. Although the resolution of this microscope allowed excellent images of morphological details, the uneven topography of the rock surface made focusing difficult. The major benefit of epifluo- rescence and confocal laser microscopy is that samples do not need prior preparation, although they do have to be observed within 1 to $2 \mathrm{~h}$ of collection (MacLulich 1986a), which could be a drawback when processing large numbers of samples or when travel times between site and laboratory are great.

These techniques were compared with air dried rock chips viewed by SEM as recommended by Hill \& Hawkins (1990) MacLulich (1986a) concluded that dehydration during air-drying and high vacuum in the SEM, destroyed all the fragile cells except diatoms. Thompson et al. (1996) have suggested that the SEM was a poor method to enumerate cyanobacteria when compared to confocal laser microscopy. In the present study, however, the SEM was qualitatively superior over other microscopes. All the species previously observed in the biofilm (Nagarkar pers. obs. using a variety of techniques) were preserved in air dried samples and were distinguishable under SEM. Most of the taxa $(>80 \%)$ could be identified by using high magnification $(>1000 \times)$. One advantage of the SEM is that samples can be fixed immediately in glutaraldehyde and stored in a vacuum desiccator for up to 1 yr without deterioration (Nagarkar unpubl. data). This technique does have the disadvantage of a relatively long sample preparation time ( 1 to $2 \mathrm{~h}$ for glutaraldehyde fixation and overnight for air drying).

SEM has been successfully utilized by some workers (Nicotri 1977, Hill \& Hawkins 1991), using a variety of preservation techniques. The most detailed results (i.e. greater species number and abundance) in this study were obtained in air dried samples. The morphology of some of these species/groups appeared shrunken or damaged by various preparation techniques while other species had clear images. Difficulties in species identification were, however, noticed due to poor preservation of the surface morphology of some algae (e.g. Hapalospongidion in critical-point dried specimens and filamentous cyanobacteria under Cryostage). Critical-point drying damages many species and may also remove loosely attached species giving an underestimate of diversity (Hill \& Hawkins 1990, 1991. Thompson et al. 1996). Cryo-stage preparation and critical-point drying techniques are also time consuming procedures, thereby reducing the number of samples which can be processed.

For species quantification SEM was superior to other microscopy techniques. Air dried samples can be used for routine quantitative analysis as sample preparation is easy and relatively fast as compared to other SEM techniques and preserves the biofilm apparently without detaching or damaging any species. Since all the species are not clearly visible in air dried samples, the use of Cryo-stage and critical-point dried samples is recommended for species identification. 


\section{Chlorophyll a extraction techniques}

Acetone has been a standard solvent to extract chlorophyll a and is still used (e.g. Davies \& Williams 1995). Methanol and ethanol are, however, more efficient solvents than acetone (methanol: Hill \& Hawkins 1990, this study; ethanol: Takada 1993, this study). The extraction efficiency of cold ethanol is similar to cold methanol (Nusch 1980, Jespersen \& Christoffersen 1987, this study), making ethanol a safe alternative to methanol, although some workers have found methanol to be superior (Arvola 1981, Riemann \& Ernst 1982). Caution should be exercised when recommending a single solvent, however, as the extraction efficiency of solvents is often species specific and, therefore, difficult to standardize (Nusch 1980, Arvola 1981, Riemann \& Ernst 1982, Jespersen \& Christoffersen 1987).

The extraction efficiency of solvents improved with increased heating time and with variable cooling time or when used cold. Solvents heated for a short time ( $30 \mathrm{~s}$ or $2 \mathrm{~min}$ ) were less efficient, only extracting 60 to $80 \%$ of extractable chlorophyll a, whereas longer heating and variable cooling extracted more than $90 \%$ of available chlorophyll a. Heating is known to influence extraction, optimizing extraction especially when Chlorophyta and Cyanophyta are present (HolmHansen \& Riemann 1978, Nusch 1980, Riemann \& Ernst 1982). On the basis of current results, cold methanol or methanol heated for 2 min and cooled for 3 and $6 \mathrm{~h}$ or ethanol heated for 5 min should be used as these treatments extract more than $95 \%$ of the available chlorophyll a. Double extraction is, however, usually needed for $100 \%$ chlorophyll a extraction. This study recommends the use of cold methanol for cyanobacteria-rich biofilms, which extracts $-96 \%$ of available chlorophyll $a$ and does not require the use of a fume hood. Methanol heated for $2 \mathrm{~min}$ and cooled for $12 \mathrm{~h}$ is the most efficient treatment since it extracts $100 \%$ chlorophyll a in a single extraction, but this method is relatively time-intensive and requires a fume hood.

The physical state of the sample, and subsequent storage conditions, also affects chlorophyll a extraction efficiency. Samples can be stored in either moist or dry conditions at $4^{\circ} \mathrm{C}$ or room temperature in the dark, but samples stored for $1 \mathrm{wk}$ had reduced chlorophyll a levels as compared to fresh, non-stored, samples or to samples stored at $-20^{\circ} \mathrm{C}$, which had chlorophyll levels similar to fresh samples even after 1 mo. Stal et al. (1984) also reported no loss of chlorophyll a in samples stored at $-20^{\circ} \mathrm{C}$ for $1 \mathrm{mo}$, and Holm-Hansen \& Riemann (1978) reported no significant loss of chlorophyll $a$ in samples stored at $-20^{\circ} \mathrm{C}$ for 2 to $3 \mathrm{wk}$ before extracting with acetone. No significant loss of chlorophyll. a after extraction over a week demonstrated that the extract could be stored for $1 \mathrm{wk}$ in the dark before measurement

Standardization of protocols to investigate the biomass and diversity of biofilms is essential to ensure accurate, repeatable measurements of chlorophyll a which can be used for comparative purposes (see Bustamante et al. 1995). Extraction techniques have been very variable in epilithic biofilm studies. Many workers have extracted chlorophyll a within $12 \mathrm{~h}$ of collection and in the dark, but other important factors for precise estimation are unclear, such as the extraction efficiency of the solvent and confirmation of complete extraction. Workers who used acetone (MacLulich 1986a, Davies \& Williams 1995) and hot methanol (boiled for less than 1 min; Hill \& Hawkins 1990, 1991. Williams 1993, 1994a, b) are likely to have underestimated chlorophyll a concentration, although this data would still allow comparative assessment between tidal heights or experimental treatments.

As extraction efficiency of solvents appears to be species specific, a prior knowledge of species composition in the sample is required. It is important, therefore, to verify species compasition of the samples and the efficiency of the selected solvent for those species. In this study, for example, it was very difficult to extract chlorophyll a using a short heating time from encrusting cyanobacteria (particularly Kyrtuthrix) whereas extraction was highly efficient from loosely attached cyanobacteria (Nagarkar pers. obs.). Analysis of fresh samples within $12 \mathrm{~h}$ of collection is recommended, but samples can be stored up to $24 \mathrm{~h}$ either at $4^{\circ} \mathrm{C}$ or at room temperature in a moist or dry condition. Storage longer than this is not recommended, but samples can be stored in a frozen condition $\left(-20^{\circ} \mathrm{C}\right)$ for over 1 mo. The final choice of protocol is, however, a trade off between sample preparation and scoring time, extraction time and the number of samples. A technique which yields $>95 \%$ efficiency in a relatively short period is preferred to one which takes more time but may achieve $100 \%$ extraction if a great number of samples need to be processed.

Acknowledgements. We are grateful to Mr N. Mok, Ms A. Wong, Mr W. S. Lee of The Electron Microscope Unit, The University of Hong Kong (H.K.U.), for their kund help with SEM sample preparation and observation. Mr J. Tam kindly helped with confocal laser microscopy, and $\mathrm{Mr} \mathrm{A}$. Lee assisted in the production of photographs. The manuscript was improved by comments from Drs R. Kennish and $Y$ M. Mak (H.K.U.). This research was conducted in partial fulfillment of a Ph.D. degree by S.N. who gratefully acknowledges a Postgraduate Studentship provided by H.K.U. This research was partially supported by a CRCG grant from H.K.U. to G.A.W 


\section{LITERATURE CITED}

Arvola L (1981) Spectrophotometric determination of chlorophyll $a$ and phaeopigments in ethanol extraction. Ann Bot Fenn 18:221-227

Bustamante RH, Branch GM, Eekhout S, Robertson B, Zoutendyk P, Schleyer M, Dye A, Hanekom N, Keats D, Jurd M, McQuaid C (1995) Gradients of intertidal primary productivity around the coast of South Africa and thejr relationships with consumer biomass. Oecologia 102:189-201

Castenholz RW' (1963) An experimental study of the vertical distribution of littoral manne datoms. Limnol Oceanogr $8: 450-462$

Danish Standard (1985) Klorofyl bestemmelse. Rapp Miljostyrelsen

Davies MS, Williams GA (1995) Pedal mucus of a tropical limpet, Cellana grata (Gould): energetics, production and fate. J Exp Mar Biol Ecol 186:77-87

Desikachary TV (1959) Cyanophyta. Indian Council of Agriculture Research, New Delhi

Dye AH, White DRA (1991) Intertidal microalgal production and molluscan herbivory in relation to season and elevation on two rocky shores on the east coast of Southern Africa. S Afr J Mar Sci 11:483-489

Hill AS, Hawkins SJ (1990) An investigation of methods for sampling microbial films on rocky shores. $J$ Mar Biol Assoc UK 70:77-88

Hill AS, Hawkins SJ (1991) Seasonal and spatial variation of epilithic microalgal distribution and abundance and its ingestion by Patella vulgata on a moderately exposed rocky shore. J Mar Biol Assoc UK 7 1:403-423

HMSO (1986) The determination of chlorophyll a in aquatic environments. In: Methucis for the examination of water and associated materials, Vol 4, Section 2. HMSO, London

Holm-Hansen O, Riemann B (1978) Chlorophyll a determination: improvements in methodology. Oikos 30:438-447

ISO 10260 (1992) Water quality-measurement of biochemical parameters-Spectrometric determination of chlorophyl] a concentration. Reference No. ISO 10260:1992 (E), Geneva, Switzerland

Jespersen AM, Christoffersen K (1987) Measurements of chlorophyll a from phytoplankton using ethanol as extraction solvent. Arch Hydrobiol 109:445-454

Jones JG (1974) A method for observation and enumeration of epilithic algae directly on the surface of stones. Oecologia 16:1-8

MacLulich JH (1986a) Experimental evaluation of methods for sampling and assaying intertidal epilithic microalgae. Mar Ecol Prog Ser 34:275-280

MacLulich JH (1986b) Colonization of bare rock surfaces by microflora in a rocky intertidal habitat. Mar Ecol Prog Ser 32:91-96

MacLulich JH (1987) Variations in the density and variety of intertidal epilithic microflora. Mar Ecol Prog Ser 40: $285-293$

Marker AFH (1972) The use of acetone and methanol in the estimation of chlorophyll in the presence of phaeophytin. Freshwat Biol 2:361-385

Meyns S, Illi R, Ribi B (1994) Comparison of chlorophyll a analysis by HPLC and spectrophotometry: Where do the differences come from? Arch Hydrobiol 132:129-139

Moed JR, Hallegraeff GM (1978) Some problems in the estimation of chlorophyll $a$ and phaeopigments from pre- and post-acidification spectrophotometric measurements. Int Revue Ges Hydrobiol 63:787-800
Nagarkar S (1996) The ecology of intertidal epilithic biofilms with special reference to cyanobacteria. PhD thesis, University of Hong Kong

Nicotri ME (1977) Grazing effects of four marine intertidal herbivores on the microflora. Ecology 58:1020-1032

Nusch EA (1980) Comparison on different methods for chlorophyll and phaeopigment determination. Arch Hydrobiol Beih Ergebn Limnol 14:14-36

Nusch EA, Palme G (1975) Biologische Methoden für die Praxis der Gewässeruntersuchung, Bestimmung des Chlorophyll a und Phaeopigmentgehaltes in Oberflächenwasser. GWF-Wasser/Abwasser 116:562-565

Potts M (1980) Blue-green algae (Cyanophyta) in marine coastal environments of the Sinai Peninsula; distribution, zonation, stratification and taxonomic diversity. Phycologia 19:60-73

Raghukumar C, Nagarkar S, Raghukumar S (1992) Association of thraustochytrids and fungi with living marine algae. Mycol Res 96:542-546

Riemann B, Ernst D (1982) Extraction of chlorophylls $a$ and $b$ from phytoplankton using standard extraction techniques. Freshwat Biol 12:217-223

Sand-Jensen K (1976) A comparison of chlorophyll a determinations of unstored and stored plankton filters extracted by methanol and acetone. Vatten 4:337-341

Stal LJ, van Gemerden H, Krumbein WE (1984) The simultaneous assay of the chlorophyll and bacteriochlorophyll in natural microbial communities. J Microbiol Methods 2: $295-306$

Takada Y (1993) Evaluation of methods for chlorophyll estimation of littoral epilithic microalgae. Benthos Res 44:45-55

Thompson RC, Wilson BJ, Tobin ML, Hill A.S, Hawkins SJ (1996) Biologically generated habitat provision and diversity of rocky shore organisms at a hierarchy of spatial scales. J Exp Mar Biol Ecol 202:73-84

Underwood AJ (1984a) The vertical distribution and seasonal abundance of intertidal microalgae on a rocky shore in New South Wales. J Exp Mar Biol Ecol 78:199-220

Underwood A.J (1984b) Microalgal food and the growth of the intertidal Gastropods Nerita atramentosa Reeve and Bembicium nanum (Lamarck) at four heights on a shore. J Exp Mar Biol Ecol 79:277-291

Williams GA (1993) The relationship between herbivorous molluscs and algae on moderately exposed Hong Kong shores. In: Morton BS (ed) Proceedings of the First International Conference on the Marine Biology of Hong Kong and the South China Sea. Hong Kong University Press, Hong Kong, p 459-469

Williams GA (1994a) Grazing by high-shore littorinids on a moderately exposed tropical rocky shore. In: Morton BS (ed) Proceedings of the Third International Workshop on the Malacofauna of Hong Kong and Southern China. Hong Kong University Press, Hong Kong, p 379-389

Williams GA (1994b) The relationship between shade and molluscan grazing in structuring communities on a moderately-exposed tropical rocky shore. J Exp Mar Biol Ecol 178:79-95

Wintermanns JFGM, DeMots A (1965) Spectrophotometric characteristics of chlorophylls $a$ and $b$ and their phaeophytins in ethanol. Biochim Biophys Acta 109:448-453

Wood LW (1985) Chloroform-methanol extraction of chlorophyll a. Can J Fish Aquat Sci 42:38-43

Zar JH (1984) Biostatistical analysis, 2nd edn. Prentice-Hall, Inc, Englewood Cliffs, NJ

Manuscript received: February 2, 1997

Revised version accepted: May 13, 1997 